
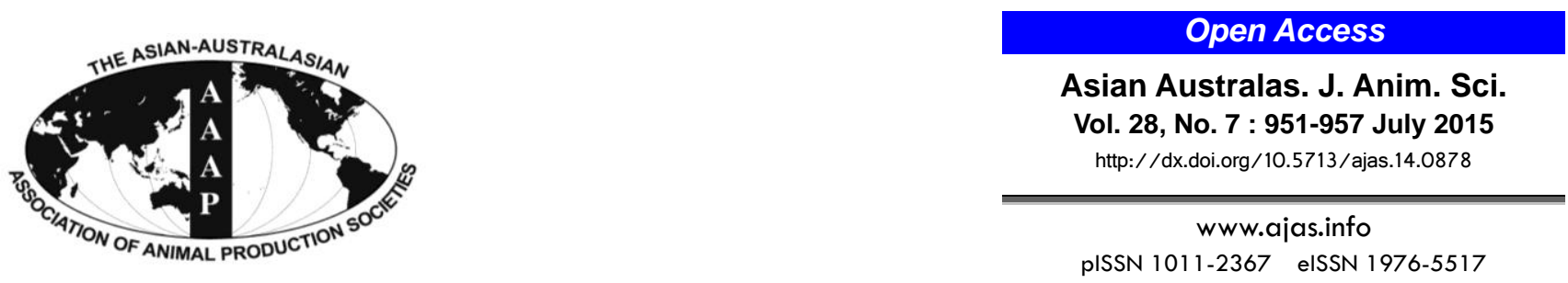

\title{
Effects of Supplementation of Eucalyptus (E. Camaldulensis) Leaf Meal on Feed Intake and Rumen Fermentation Efficiency in Swamp Buffaloes
}

\author{
N. T. Thao ${ }^{1,2}$, M. Wanapat ${ }^{2} *$, S. Kang ${ }^{3}$, and A. Cherdthong ${ }^{2}$ \\ ${ }^{1}$ Department of Animal Science and Veterinary medicine, An Giang University, An Giang 94000, Vietnam
}

\begin{abstract}
Four rumen fistulated swamp buffaloes were randomly assigned according to a $4 \times 4$ Latin square design to investigate the effects of Eucalyptus (E. Camaldulensis) leaf meal (ELM) supplementation as a rumen enhancer on feed intake and rumen fermentation characteristics. The dietary treatments were as follows: T1 $=0 \mathrm{~g}$ ELM/hd/d; T2 $=40 \mathrm{~g} \mathrm{ELM} / \mathrm{hd} / \mathrm{d} ; \mathrm{T} 3=80 \mathrm{~g} \mathrm{ELM} / \mathrm{hd} / \mathrm{d} ; \mathrm{T} 4$ $=120 \mathrm{~g} \mathrm{ELM} / \mathrm{hd} / \mathrm{d}$, respectively. Experimental animals were kept in individual pens and concentrate was offered at $0.3 \% \mathrm{BW}$ while rice straw was fed ad libitum. The results revealed that voluntary feed intake and digestion coefficients of nutrients were similar among treatments. Ruminal pH, temperature and blood urea nitrogen concentrations were not affected by ELM supplementation; however, ELM supplementation resulted in lower concentration of ruminal ammonia nitrogen. Total volatile fatty acids, propionate concentration increased with the increasing level of EML $(\mathrm{p}<0.05)$ while the proportion of acetate was decreased $(\mathrm{p}<0.05)$. Methane production was linearly decreased $(\mathrm{p}<0.05)$ with the increasing level of ELM supplementation. Protozoa count and proteolytic bacteria population were reduced $(\mathrm{p}<0.05)$ while fungal zoospores and total viable bacteria, amylolytic, cellulolytic bacteria were unchanged. In addition, nitrogen utilization and microbial protein synthesis tended to increase by the dietary treatments. Based on the present findings, it is suggested that ELM could modify the rumen fermentation and is potentially used as a rumen enhancer in methane mitigation and rumen fermentation efficiency. (Key Words: Eucalyptus Leaf Meal, Rice Straw, Rumen Fermentation, Swamp Buffalo)
\end{abstract}

\section{INTRODUCTION}

In ruminants, nutrients input are the first to fermentative digestion by ruminal microorganisms. Methane $\left(\mathrm{CH}_{4}\right)$ production through enteric fermentation is of concern worldwide for its contribution to the accumulation of greenhouse gases in the atmosphere, as well as its being a waste of fed energy (Boadi et al., 2004). There is an interest in decreasing $\mathrm{CH}_{4}$ emission by inhibition of ruminal methanogens thus increasing the efficiency of feed energy utilization for ruminants and would have significant

\footnotetext{
* Corresponding Author: M. Wanapat. Tel: +66-4320-2368, Fax: +66-4320-2368, E-mail: metha@kku.ac.th

${ }^{2}$ Tropical Feed Resources Research and Development Center, (TROFREC), Department of Animal Science, Faculty of Agriculture, Khon Kaen University, Khon Kaen 40002, Thailand.

${ }^{3}$ Agricultural Unit, Department of Education, National Institute of Education, Phnom Penh 12401, Cambodia.

Submitted Nov. 17, 2014; Revised Feb. 4, 2015; Accepted Feb. 27, 2015
}

economic and environmental benefits (Guglielmelli et al., 2010; Benchaar and Greathead, 2011; Calabrò et al., 2013). Therefore, developing feeding strategies for ruminants with a methane suppressing impact are desirable and inhibition of methanogensis has long been considered as a strategy to improve animal productivity (Wanapat et al., 2013a,b).

Recently, animal nutritionists have paid more attention to manipulating rumen microbial ecosystems in order to reduce methane emission and $\mathrm{N}$ excretion by ruminants with the aim to improving feed conversion efficiency. Plant secondary metabolites, which are well documented as antimicrobial agents, are considered as potential candidates to achieve this objective, as they are available in large number and viewed as natural products that are safe for humans (Wanapat et al., 2013c; 2014). Eucalyptus is one of the world's important and most widely planted genera. Among its main uses is the production of essential oils (EO) used for medicinal and pharmaceutical purposes. Essential oil from the leaves of Eucalyptus camaldulensis ranges 
from less than $1 \%$ to over $2 \%$. As reported by Elaissi et al. (2012), eucalyptus contents several kinds of EO, the main components were 1,8 -cineole ( $4.5 \%$ to $70.4 \%$ ) followed by cryptone $(0.0 \%$ to $20.9 \%), \alpha$-pinene $(1.0 \%$ to $17.6 \%), \rho$ cymene ( $0.8 \%$ to $16.7 \%)$, $\alpha$-teprpineol $(0.6 \%$ to $10.3 \%)$. Sallam et al. $(2009,2010)$ and Thao et al. (2014) proposed that eucalyptus leaves either fresh or as distilled eucalyptus oils have potential biological activities such as bacteriostatic, fungistatic, anti-inflommatory, modifying ruminal fermentation characteristics, anti-protozoal and methane mitigration. However, there are limited experimental data on effects of Eucalyptus leaves on rumen digestion and fermentation patterns, especially in swamp buffaloes. Therefore, the objective of this study was to evaluate the effects of Eucalyptus leaf meal (ELM) supplementation on feed intake and rumen fermentation characteristics of swamp buffaloes.

\section{MATERIALS AND METHODS}

\section{Animal, feeds and management}

Four, ruminal fistulated buffaloes, 4 years old with initial body weight (BW) of $321 \pm 20 \mathrm{~kg}$, were randomly assigned to receive four dietary treatments according to a $4 \times 4$ Latin square design. The dietary treatments were based on different levels of ELM supplementation at 0, 40, 80, and $120 \mathrm{~g} / \mathrm{hd} / \mathrm{d}$, respectively. Concentrate was fed daily at $0.3 \% \mathrm{BW}$ and rice straw was offered ad libitum. The experiment was conducted for four periods and each lasted for 21 days. During the first 14 days, all animals were fed respective diets; whereas during the last 7 days, animals were moved to metabolism crates for total urine and fecal collection as well as rumen fluid and blood sampling.

\section{Data collection and sampling procedures}

Feeds and fecal samples were collected during the last 7 days of each period, dried at $60^{\circ} \mathrm{C}$ and ground to pass a 1$\mathrm{mm}$ screen using a Cyclotech Mill (Tecator, Höganäs, Sweden) and were analyzed using standard methods of AOAC (1995) for dry matter (DM), ash, and acid detergent fiber (ADF). Neutral detergent fiber (NDF) in samples was estimated according to Van Soest et al. (1991) with the addition of $\alpha$-amilase but without sodium sulphite and the results were calculated with residual ash. Total nitrogen $(\mathrm{N})$ of feeds, refusals and fecal samples were determined according to AOAC (1995).

At the last day of each period, rumen fluid and jugular blood samples were collected immediately post feeding at 2 , 4 , and $6 \mathrm{~h}$. Rumen fluid was immediately measured for $\mathrm{pH}$ and temperature using a portable $\mathrm{pH}$ temperature meter. Ruminal ammonia nitrogen $\left(\mathrm{NH}_{3}-\mathrm{N}\right)$ was analyzed by micro Kjeltech Auto 1030 Analyzer (AOAC, 1995), volatile fatty acids (VFA) were analyzed by using high pressure liquid chromatography (HPLC) according to Samuel et al. (1997). Rumen fluid was also determined for direct count of protozoa and fungal zoospores using the methods described by Galyean (1989) by a haemacytometer (Boeco, Singapore) and bacteria (total viable, cellulolytic, amylolytic, and proteolytic) were measured using roll-tube technique (Hungate, 1969). A blood sample collected from the jugular vein at the same time as rumen fluid sampling was separated by centrifugation and stored at $-20^{\circ} \mathrm{C}$ until analysis for blood urea nitrogen (BUN) according to Crocker (1967).

Urine samples were analyzed for total N (AOAC, 1995) and allantoin in urine was determined by HPLC as described by Chen et al. (1993). The amount of microbial purine derivatives $(\mathrm{PD})$ absorption was calculated from $\mathrm{PD}$ excretion based on the relationship derived by the equation of Liang et al. (1994): $\mathrm{Y}=0.12 \mathrm{X}+\left(0.02 \mathrm{BW}^{0.75}\right)$. The supply of microbial $\mathrm{N}(\mathrm{MN})$ was estimated by urinary excretion of PD according to Chen and Gome (1995): $\mathrm{MN}(\mathrm{g} / \mathrm{d})=$ $70 \mathrm{X} /(0.016 \times 0.83 \times 1,000)=0.727 \mathrm{X}$; where $\mathrm{X}$ and $\mathrm{Y}$ are, respectively, absorption and excretion of PD in $\mathrm{mmol} / \mathrm{d}$. Efficiency of microbial $\mathrm{N}$ synthesis (EMNS) was calculated using the following formula: EMNS $=$ microbial $\mathrm{N}$ $(\mathrm{g} / \mathrm{d}) / \mathrm{DOMR}$; where DOMR = digestible organic matter (OM) apparently fermented in the rumen (assuming that rumen digestion was $650 \mathrm{~g} / \mathrm{kg}$ OM of digestion in total tract; DOMR $=\mathrm{DOMI} \times 0,65 ; \mathrm{DOMI}=$ digestible organic matter in take).

\section{Statistical analyses}

All obtained data were subjected to analysis of variance according to a $4 \times 4$ Latin square design using the general linear models procedures of the Statistical Analysis System Institute (SAS, 1998). The results are presented as mean values with the standard error of the means. Differences among means with $\mathrm{p}<0.05$ was accepted as representing statistical differences. Treatment means were compared by orthogonal polynomials by Duncan's New Multiple Rang Test (Steel and Torrie, 1980).

\section{RESULTS AND DISCUSSION}

\section{Chemical composition of diets}

Table 1 shows feed ingredient and chemical compositions of concentrate, rice straw and ELM used during the four experimental periods. The concentrate consisting of available local feed resources such as cassava chip, rice bran, palm kernel meal, molasses, urea and minerals had a higher quality in terms of crude protein (CP) and low in NDF (14.2\% and 16.0\% DM, respectively), while rice straw contained a low level of CP but was high in NDF (3.2\% and $76.2 \%$ DM, respectively) which was consistent with the study of Wanapat et al. (2013d). On the 
Table 1. Ingredients and chemical composition of experimental diets

\begin{tabular}{|c|c|c|c|}
\hline Items & Concentrate & Rice straw & ELM \\
\hline \multicolumn{4}{|l|}{ Ingredients (\%) } \\
\hline Cassava chip & 65.0 & & \\
\hline Rice bran & 10.0 & & \\
\hline Palm meal & 20.2 & & \\
\hline Urea & 1.5 & & \\
\hline Molasses & 1.5 & & \\
\hline Sulfur & 0.3 & & \\
\hline Premix mineral $^{1}$ & 1.0 & & \\
\hline Salt & 0.5 & & \\
\hline \multicolumn{4}{|l|}{ Chemical composition (\%) } \\
\hline Dry matter & 93.2 & 95.6 & 93.5 \\
\hline Organic matter & 94.7 & 87.5 & 94.0 \\
\hline Ash & 5.3 & 12.5 & 6.0 \\
\hline Crude protein & 14.2 & 3.2 & 9.5 \\
\hline Neutral detergent fiber & 16.0 & 76.2 & 34.3 \\
\hline Acid detergent fiber & 8.4 & 47.2 & 22.0 \\
\hline Tannins & - & - & 9.0 \\
\hline
\end{tabular}

ELM, Eucalyptus leaf meal.

${ }^{1}$ Minerals and vitamins premix: vitamin A, 10,000,000 IU; vitamin E, 70,000 IU; Vitamin D, 1,600,000 IU; Fe, 50 g; Zn, 40 g; Mn, 40 g; Co, $0.1 \mathrm{~g} ; \mathrm{Se}, 0.1 \mathrm{~g} ; \mathrm{I}, 0.5$.

other hand, ELM contained CP up to $9.5 \% \mathrm{DM}$ and was low in NDF and $\mathrm{ADF}$ (34.4\% and $22.0 \% \mathrm{DM}$, respectively). Moreover, ELM contained tannin 9.0\% DM. These values were similar to the finding of Manh et al. (2012). Sallam et al. (2010) who found that Eucalyptus fresh leaves had CP: 7.64\%, NDF 61.62\%, and ADF 50.4\%. Moreover, Brooker and Kleinig (2006) suggested that the chemical composition of Eucalyptus and the individual concentration these chemicals varies with the species, season, location, climate, soil type, age of the leaves, fertility regime and the method used for drying the plant material.

\section{Feed intake and nutrient digestibility}

The effects of ELM supplementation on total dry mater intake and nutrient digestibility are presented in Table 2 . Results of this study indicate that supplementing swamp buffaloes with ELM had no effect on feed intake. The effects of feeding essential oils (EO) or their components on feed intake have been variable depending on the type and dose of EO used (Patra et al., 2010; Thao et al., 2014). Reports on the effect of EO or their components on feed intake are very scarce because of the reduction of palatability (Salem et al., 2006). For instance, Cardozo et al. (2006) reported that supplementation of a mixture of cinnamaldehyde $(0.6 \mathrm{~g} / \mathrm{d})$ and eugenol $(0.3 \mathrm{~g} / \mathrm{d})$ oils decreased dry matter intake in dairy heifers. Furthermore, Benchaar et al. (2006) indicated that feeding dairy cows at 2 $\mathrm{g} / \mathrm{d}$ of EO containing a mixture of thymol, eugenol, vanillin, and limonene decreased feed intake. In contrast, a low level of EO supplementation may stimulate feed intake. Similarly, testing a variety of EO including cinnamaldehyde, garlic, and juniper berry at $200 \mathrm{mg} / \mathrm{kg}$ of dietary DM fed to lambs, Chaves et al. (2008) did not find any effects on intake when the flavors were included in sheep diets. More recently, Giannenas et al. (2011) reported no change in DM in dairy ewes when supplemented with EO at $150 \mathrm{mg} / \mathrm{kg}$ of concentrate feed.

Apparent digestibility of DM, OM, CP, NDF, and ADF were not significantly different $(p>0.05)$ among treatments

Table 2. Effects of Eucalyptus leaf meal supplementation on voluntary feed intake and nutrient digestibility

\begin{tabular}{|c|c|c|c|c|c|c|c|c|}
\hline \multirow{2}{*}{ Items } & \multicolumn{4}{|c|}{ ELM (g/hd/d) } & \multirow{2}{*}{ SEM } & \multicolumn{3}{|c|}{ Contrast } \\
\hline & 0 & 40 & 80 & 120 & & $\mathrm{~L}$ & $\mathrm{Q}$ & $\mathrm{C}$ \\
\hline \multicolumn{9}{|c|}{ Rice straw intake } \\
\hline $\mathrm{kg} / \mathrm{d}$ & 5.5 & 5.4 & 5.2 & 5.3 & 0.26 & ns & $\mathrm{ns}$ & ns \\
\hline$\% \mathrm{BW}$ & 1.7 & 1.8 & 1.8 & 1.6 & 0.52 & ns & $\mathrm{ns}$ & ns \\
\hline \multicolumn{9}{|c|}{ Concentrate intake } \\
\hline $\mathrm{kg} / \mathrm{d}$ & 0.9 & 0.9 & 0.9 & 0.9 & 0.05 & ns & $\mathrm{ns}$ & ns \\
\hline$\% \mathrm{BW}$ & 0.3 & 0.3 & 0.3 & 0.3 & 0.05 & ns & $\mathrm{ns}$ & ns \\
\hline \multicolumn{9}{|c|}{ Total intake } \\
\hline $\mathrm{kg} / \mathrm{d}$ & 6.4 & 6.3 & 6.1 & 6.3 & 0.30 & ns & $\mathrm{ns}$ & ns \\
\hline$\% \mathrm{BW}$ & 1.9 & 2.0 & 2.0 & 1.8 & 0.05 & ns & ns & ns \\
\hline \multicolumn{9}{|c|}{ Apparent digestibility (\%) } \\
\hline $\mathrm{DM}$ & 63.9 & 62.3 & 60.1 & 58.8 & 1.87 & ns & $\mathrm{ns}$ & $\mathrm{ns}$ \\
\hline $\mathrm{OM}$ & 68.3 & 66.6 & 65.6 & 64.5 & 2.13 & ns & $\mathrm{ns}$ & $\mathrm{ns}$ \\
\hline $\mathrm{CP}$ & 61.8 & 60.2 & 59.6 & 59.1 & 1.60 & $\mathrm{~ns}$ & $\mathrm{~ns}$ & $\mathrm{~ns}$ \\
\hline $\mathrm{NDF}$ & 54.5 & 53.2 & 52.4 & 51.8 & 1.73 & ns & $\mathrm{ns}$ & $\mathrm{ns}$ \\
\hline $\mathrm{ADF}$ & 61.8 & 58.9 & 58.2 & 57.3 & 2.40 & ns & $\mathrm{ns}$ & ns \\
\hline
\end{tabular}

ELM, Eucalyptus leaf meal; SEM, standard error of the mean; L, linear; Q, quadratic, C, cubic; ns, non-significant; BW, body weight; DM, dry matter; $\mathrm{OM}$, organic matter; $\mathrm{CP}$, crude protein; NDF, neutral detergent fiber; ADF, acid detergent fiber. 
in the present study. Moreover, Sallam et al. (2009) observed that supplementation of Eucalyptus oil did not affect on in vitro DM and OM digestibility. Furthermore, Santos et al. (2010) reported that the digestibility of feed was not affected when supplementation of EO complex to the diet of lactating dairy cows.

\section{Rumen fermentation characteristics}

Effects of ELM supplementation on rumen fermentation efficiency and BUN are presented in Table 3. Ruminal temperature, $\mathrm{pH}$ and $\mathrm{BUN}$ were similar among treatments and the values were stable at $38.5^{\circ} \mathrm{C}$ to $38.6^{\circ} \mathrm{C}, 6.4-6.6$, and 9.3-9.4 mg/dL, respectively. However, the concentration of $\mathrm{NH}_{3}-\mathrm{N}$ was found the lowest in the treatment with $120 \mathrm{~g}$ $\mathrm{ELM} / \mathrm{h} / \mathrm{d}$ supplementation and the highest was in the control group. Castillejos et al. (2007) studied long term effect of EO on rumen fermentation in vivo also found that supplementation EO resulted in lower ruminal ammonia-N when compared to that in control. Several studies (Newbold et al., 2004; Patra and Saxena, 2009) demonstrated that EO might inhibit the hyper-ammonia producing bacteria in the rumen, which results in decreased amino acid deamination, consequently, lowering rumen $\mathrm{NH}_{3}-\mathrm{N}$.

As shown, supplementation of ELM resulted in increasing total VFA concentration $(\mathrm{p}<0.05)$ and propionate molar concentration, while the molar proportion of acetate was decreased $(\mathrm{p}<0.05)$ with an increased level of ELM in the diets, concomitantly, calculated methane production was also decreased $(\mathrm{p}<0.05)$. The total VFA concentrations in the rumen were generally slightly affected (Chaves et al., 2008; Patra et al., 2010) or decreased especially at higher levels of supplemented EO. However, recent observed was similar with Chaves et al. (2008) and Wang et al. (2009) when supplementation of EO was given to sheep. The ELM supplementation caused a shift in end products of rumen fermentation with a reduction of acetate proportion and acetate : propionate ratio and was in agreement with several works in in vitro (Castillejos et al., 2006) and in vivo (Giannenas et al., 2011).

Calculated methane production based on molar VFA according to Moss et al. (2000) in present study showed that methane production was reduced and was in agreement with in vitro (Sallam et al., 2009) and in vivo (Wang et al., 2009). Modification of the fermentative profiles could be a result of inhibition of Archae (methanogens) and gram positive rumen microbes (i.e., acetate producers) as reviewed by Benchaar and Greathead (2011). In addition, this was accompanied with a reduction of protozoa count by ELM supplementation treatments, which could further explain the decreased methane production since ruminal protozoa provide a habitat for methanogens.

\section{Rumen microbial population}

Table 4 illustrates data on rumen microbes affected by ELM supplementation using direct count and roll tube technique. The present results show that total viable bacterial and fungal zoospores count were not changed in the supplemented diets. In contrast, proteolytic bacteria and protozoa were decreased in the ELM supplementation groups as compared with the control group. Several authors have suggested certain effects of EO compounds on specific bacteria populations. However, such effects of EO compounds on ruminal microbial populations are inconclusive (Wallace et al., 2008). For instance, Newbold et al. (2004) reported that ruminal protozoa counts were not affected when sheep and dairy cows were fed with 110 and $750 \mathrm{mg} / \mathrm{d}$ of a mixture of EO, respectively. Moreover, supplementation of dairy cows diets with $0.5 \mathrm{~g}$ of cinnamaldehyde per liter of rumen fluid had also no effect on the number of ciliate protozoa (Fraser et al., 2007). In contrast, Ando et al. (2003) observed that total number of protozoa was decreased when dairy steers were fed $200 \mathrm{~g} / \mathrm{d}$ of peppermint.

Table 3. Effect of Eucalyptus leaf meal on rumen fermentation characteristics

\begin{tabular}{|c|c|c|c|c|c|c|c|c|}
\hline \multirow{2}{*}{ Items } & \multicolumn{4}{|c|}{ ELM (g/hd/d) } & \multirow{2}{*}{ SEM } & \multicolumn{3}{|c|}{ Contrast } \\
\hline & 0 & 40 & 80 & 120 & & $\mathrm{~L}$ & $\mathrm{Q}$ & $\mathrm{C}$ \\
\hline Ruminal pH & 6.6 & 6.5 & 6.4 & 6.5 & 0.06 & $\mathrm{~ns}$ & $\mathrm{~ns}$ & $\mathrm{~ns}$ \\
\hline Ruminal temperature $\left({ }^{\circ} \mathrm{C}\right)$ & 38.6 & 38.6 & 38.5 & 38.6 & 0.05 & ns & ns & ns \\
\hline Blood urea nitrogen $(\mathrm{mg} / \mathrm{dL})$ & 9.3 & 9.3 & 9.9 & 9.4 & 1.94 & ns & $\mathrm{ns}$ & ns \\
\hline $\mathrm{NH}_{3}-\mathrm{N}(\mathrm{mg} / \mathrm{dL})$ & $11.8^{\mathrm{a}}$ & $10.3^{\mathrm{ab}}$ & $8.5^{\mathrm{ab}}$ & $7.8^{\mathrm{b}}$ & 0.99 & $*$ & $\mathrm{~ns}$ & ns \\
\hline Total VFA (mM/L) & $102.8^{\mathrm{a}}$ & $104.6^{\mathrm{ab}}$ & $106.6^{\mathrm{bc}}$ & $108.5^{\mathrm{c}}$ & 0.83 & $*$ & ns & ns \\
\hline Acetate & $68.9^{\mathrm{a}}$ & $66.7^{\mathrm{b}}$ & $\begin{array}{c}00 \mathrm{~mol}-- \\
63.2^{\mathrm{c}}\end{array}$ & $64.5^{\mathrm{c}}$ & 0.5 & * & $*$ & * \\
\hline Propionate & $18.4^{\mathrm{a}}$ & $22.2^{\mathrm{b}}$ & $24.4^{\mathrm{c}}$ & $23.6^{\mathrm{c}}$ & 0.24 & * & $*$ & ns \\
\hline Butyrate & $12.7^{\mathrm{a}}$ & $11.2^{\mathrm{b}}$ & $12.4^{\mathrm{a}}$ & $11.9^{\mathrm{ab}}$ & 0.27 & ns & $\mathrm{ns}$ & * \\
\hline $\operatorname{Methane}^{1}(\mathrm{mmol} / 100 \mathrm{~mol})$ & $31.0^{\mathrm{a}}$ & $28.4^{\mathrm{b}}$ & $26.7^{\mathrm{c}}$ & $27.3^{\mathrm{c}}$ & 0.18 & $*$ & $*$ & ns \\
\hline
\end{tabular}

ELM, Eucalyptus leaf meal; SEM, standard error of the means; L, linear; Q, quadratic; C, cubic; ns, non-significant; VFA, volatile fatty acids.

${ }^{1}$ Calculated: $\mathrm{CH}_{4}=(0.45 \times$ acetate $)-(0.275 \times$ propionate $)+(0.40 \times$ butyrate $)$ (Moss et al., 2000$)$.

a,b,c Values on the same row with difference superscript differed; $* \mathrm{p}<0.05$. 
Table 4. Effects of Eucalyptus leaf meal supplementation on rumen microbial population

\begin{tabular}{|c|c|c|c|c|c|c|c|c|}
\hline \multirow{2}{*}{ Items } & \multicolumn{4}{|c|}{ ELM (g/hd/d) } & \multirow{2}{*}{ SEM } & \multicolumn{3}{|c|}{ Contrast } \\
\hline & 0 & 40 & 80 & 120 & & $\mathrm{~L}$ & Q & $\mathrm{C}$ \\
\hline \multicolumn{9}{|l|}{ Total direct count (cell/mL) } \\
\hline Protozoa $\left(\times 10^{5}\right)$ & $9.1^{\mathrm{a}}$ & $8.6^{\mathrm{ab}}$ & $7.6^{\mathrm{ab}}$ & $7.1^{\mathrm{b}}$ & 0.51 & $*$ & ns & ns \\
\hline Fungi zoospores $\left(\times 10^{5}\right)$ & 3.9 & 3.4 & 3.2 & 4.5 & 0.40 & ns & 0.08 & ns \\
\hline \multicolumn{9}{|l|}{ Viable bacteria $(\mathrm{CFU} / \mathrm{mL})$} \\
\hline Total $\left(\times 10^{9}\right)$ & 0.7 & 0.8 & 0.8 & 1.1 & 1.13 & ns & ns & ns \\
\hline Amylolytic $\left(\times 10^{7}\right)$ & 4.7 & 3.4 & 3.1 & 5.1 & 0.91 & ns & $\mathrm{ns}$ & ns \\
\hline Proteolytic $\left(\times 10^{7}\right)$ & $6.8^{\mathrm{a}}$ & $5.7^{\mathrm{ab}}$ & $5.0^{\mathrm{b}}$ & $3.1^{\mathrm{c}}$ & 0.45 & $*$ & ns & $\mathrm{ns}$ \\
\hline Cellulolytic $\left(\times 10^{8}\right)$ & 2.0 & 1.1 & 1.2 & 1.3 & 0.33 & ns & ns & ns \\
\hline
\end{tabular}

ELM: Eucalyptus leaf meal; SEM, standard error of the means; L, linear; Q, quadratic; C, cubic; ns: non-significant; CFU, colony-forming unit.

${ }_{\mathrm{a}, \mathrm{b}, \mathrm{c}}$ Values on the same row with different superscripts differ; ${ }^{*} \mathrm{p}<0.05$.

\section{Nitrogen utilization and microbial protein synthesis}

In buffaloes the effects of ELM supplementation in concentrate with rice straw as roughage on nitrogen metabolism and efficiency of microbial protein synthesis are summarized in Table 5. The results revealed that supplementation of ELM did not affect nitrogen utilization. In this study, it was observed that positive nitrogen retention and absorption were obtained in the ELM supplemented group and were not different among treatments. Similarly, Benchaar et al. (2006) observed no change in $\mathrm{N}$ retention when cows were fed with $2 \mathrm{~g} / \mathrm{d}$ of the Crina ruminant supplement. According to Cutrignelli et al. (2007), PD excretion ranged between 28 and $34 \mathrm{mmml} / \mathrm{d}$ and was not affected by treatments. Moreover, no PD parameter was impacted by EML feeding; therefore calculated microbial protein synthesis yield also was not different among treatments which were similar to the results of Newbold et al. (2004) who reported no change in bacterial $\mathrm{N}$ flow, estimated from excretion of urinary PD, when sheep were supplemented daily with $100 \mathrm{mg}$ of mixed EO. Under this study, ELM supplementation tended to improve the $\mathrm{N}$ retention and efficiency of microbial $\mathrm{N}$ synthesis.

\section{CONCLUSION}

Based on this study, it could be concluded that supplementation of ELM could modify the rumen fermentation and has potential as an enhancer for rumen fermentation and methane mitigation. However, further studies using various levels of ELM supplementation in growing trials are recommended.

\section{ACKNOWLEDGMENTS}

Tropical Feed Resources Research and Development Center (TROFREC), Department of Animal Science, Faculty of Agriculture, Khon Kaen University, Thailand and the Vietnam International Education Development (VIED), Ministry of Education and Training, Vietnam are gratefully acknowledged for the use of research facilities and financial support, respectively.

Table 5. Effects of Eucalyptus leaf meal supplementation on nitrogen metabolism and microbial protein synthesis

\begin{tabular}{|c|c|c|c|c|c|c|c|c|}
\hline \multirow{2}{*}{ Items } & \multicolumn{4}{|c|}{ ELM (g/hd/d) } & \multirow{2}{*}{ SEM } & \multicolumn{3}{|c|}{ Contrast } \\
\hline & 0 & 40 & 80 & 120 & & $\mathrm{~L}$ & $\mathrm{Q}$ & $\mathrm{C}$ \\
\hline \multicolumn{9}{|l|}{$\mathrm{N}$ utilization $(\mathrm{g} / \mathrm{d})$} \\
\hline $\mathrm{N}$ intake & 40.8 & 41.9 & 41.1 & 42.3 & 1.05 & ns & ns & $\mathrm{ns}$ \\
\hline \multicolumn{9}{|l|}{$\mathrm{N}$ excretion } \\
\hline Feces & 26.4 & 27.1 & 26.7 & 27.4 & 0.28 & $\mathrm{~ns}$ & ns & $\mathrm{ns}$ \\
\hline Urine & 5.4 & 5.3 & 5.4 & 5.2 & 0.93 & ns & ns & $\mathrm{ns}$ \\
\hline \multicolumn{9}{|l|}{$\mathrm{N}$ balance } \\
\hline Absorption & 14.4 & 14.7 & 14.5 & 14.9 & 0.52 & ns & ns & $\mathrm{ns}$ \\
\hline Retention & 8.9 & 9.5 & 9.1 & 9.7 & 0.80 & ns & ns & $\mathrm{ns}$ \\
\hline \multicolumn{9}{|l|}{$\mathrm{PD}(\mathrm{mmol} / \mathrm{d})$} \\
\hline Allantoin excretion & 28.1 & 29.7 & 31.6 & 34.0 & 1.95 & ns & ns & $\mathrm{ns}$ \\
\hline Allantoin absorption & 108.5 & 120.7 & 140.0 & 145.4 & 15.98 & ns & ns & $\mathrm{ns}$ \\
\hline Microbial nitrogen supply (g N/d) & 78.9 & 87.8 & 101.8 & 105.7 & 11.62 & ns & ns & ns \\
\hline EMPS (g N/kg OMDR) & 32.5 & 37.3 & 42.7 & 44.0 & 4.70 & ns & ns & $\mathrm{ns}$ \\
\hline
\end{tabular}

ELM, Eucalyptus leaf meal; SEM, standard error of the mean; L, linear; Q, quadratic; C, cubic; ns, non-significant; PD, purine derivations; EMPS, efficiency of microbial nitrogen synthesis; OMDR, digestible organic matter apparently fermented in the rumen. 


\section{REFERENCES}

Ando, S., T. Nishida, M. Ishida, K. Hosoda, and E. Bayaru. 2003. Effect of peppermint feeding on the digestibility, ruminal fermentation and protozoa. Livest. Prod. Sci. 82:245-248.

AOAC. 1995. Official Methods of Analyses, 16th ed. Animal Feeds: Association of Official Analytical Chemists, Arlington, VA, USA.

Benchaar, C. and H. Greahead. 2011. Essential oils and opportunities to mitigate enteric methane emissions from ruminants. Anim. Feed Sci. Technol. 166-167:338-355.

Bencharr, C., H. V. Petit, R. Berthiaume, T. D. Whyte, and P. Y. Chouinard. 2006. Effects of addition of essential oils and monensin premix on digestion, ruminal fermentation, milk production, and milk composition in dairy cows. J. Dairy Sci. 89:4352-4364.

Boadi, D., C. Benchaar, J. Chiquette, and D. Masse. 2004. Mitigation strategies to reduce enteric methane emissions from dairy cows: Update review. Can. J. Anim. Sci. 84:319-335.

Brooker, M. I. H., and D. A. Kleinig. 2006. Field Guide to Eucalyptus. Vol.1. South-eastern Australia, Third edition. Bloomings, Melbourne, Australia.

Calabrò, S., F. Infascelli, R. Tudisco, N. Musco, M. Grossi, G. Monastra, and M. I. Cutrignelli. 2013. Estimation of in vitro methane production in buffalo and cow. Buff. Bull. 32(Special Issue 2):924-927.

Cardozo, P. W., S. Calsamiglia, A. Ferret, and C. Kamel. 2006. Effects of alfalfa extract, anise, capsicum, and a mixture of cinnamaldehyde and eugenol on ruminal fermentation and protein degradation in beef heifers fed a high-concentrate diet. J. Anim. Sci. 84:2801-2808.

Castillejos, L, S. Calsamiglia, and A. Ferret. 2006. Effect of essential oil active compounds on rumen microbial fermentation and nutrient flow in in vitro system. J. Dairy Sci. 89:2649-2658.

Castillejos, L., S. Calsamiglia, A. Ferret, and R. Losa. 2007. Effects of dose and adaptation time of a specific blend of essential oil compounds on rumen fermentation. Anim. Feed. Sci. Technol. 132:186-201.

Chaves, A. V., K. Stanford, M. E. R. Dugan, L. L. Gibson, T. A. McAllister, F. Van Herk, and C. Benchaar. 2008. Effects of cinnamaldehyde, garlic and juniper berry essential oils on rumen fermentation, blood metabolites, growth performance, and carcass characteristics of growing lambs. Livest. Sci. 117: 215-224.

Chen, X. B. and M. J. Gomes. 1995. Estimation of microbial protein supply to sheep and cattle based on urinary excretion of purine derivative-An overview of the technique details. Occasional publication 1992. International Feed Resources Unit, Rowett Research Institute, Aberdeen, UK.

Chen, X. B., D. J. Kyle, and E. R. Orskov. 1993. Measurement of allantoin in urine and plasma by high-performance liquid chromatography with pre-column derivatization. J. Chromatogr. B Biomed. Sci. Appl. 617:241-247.

Crocker, C. L. 1967. Rapid determination of urea nitrogen in serum or plasma without deproteinization. Am. J. Med. Technol. 33:361-365.

Cutrignelli, M. I., G. Piccolo, S. D'Urso, S. Calabrò, F. Bovera, R.
Tudisco, and F. Infascelli. 2007. Urinary excretion of purine derivatives in dry buffalo and Fresian cows. Ital. J. Anim. Sci. 6:563-566.

Elaissi, A., Z. Rouis, N. B. A. Salem, S. Mabrouk, Y. B. Salem, K. B. H. Salah, M. Aouni, F. Farhat, R. Chemli, F. HarzallahSkhiri, and M. L. Khouja. 2012. Chemical composition of 8 eucalyptus species' essential oils and the evaluation of their antibacterial, antifungal and antiviral activities. BMC Complement. Altern. Med. 12:81.

Fraser, G. R., A. V. Chaves, Y. Wang, T. A. McAllister, K. A. Beauchemin, and C. Benchaar. 2007. Assessment of the effects of cinnamon leaf oil on rumen microbial fermentation using two continuous culture systems. J. Dairy. Sci. 90:2315-2328.

Galyean, M. 1989. Laboratory procedure in animal nutrition research. Department of animal and range science. New Mexico State University, Las Cruces, NM, USA. pp. 107-122.

Giannenas, I., J. Skoufos, C. Giannakopoulos, M. Wiemann, O. Gortzi, S. Lalas, and I. Kyriazakis. 2011. Effects of essential oils on milk production, milk composition, and rumen microbiota in Chios dairy ewes. J. Dairy Sci. 94:5569-5577.

Guglielmelli, A., S. Calabrò, M. Cutrignelli, O. Gonzalez, F. Infascelli, R. Tudisco, and V. Piccolo. 2010. In vitro fermentation and methane production of fava and soy beans. EAAP Scientific Series 127(1):457-460.

Hungate, R. E. 1969. A Role Tube Method for Cultivation of strict Anaerobes. Method in Microbiology (Eds. J. R. Norris and D. W. Ribbons). Academic Press, New York, NY, USA. 313.

Liang, J. B., M. Matsumoto, and B. A. Young. 1994. Purine derivative excretion and ruminal microbial yield in Malaysian cattle and swamp buffalo. Anim. Feed Sci. Technol. 47:189199.

Manh, N. S., M. Wanapat, S. Uriyapongson, P. Khejornsart, and V. Chanthakhoun. 2012. Effect of eucalyptus (Camaldulensis) leaf meal powder on rumen fermentation characteristics in cattle fed on rice straw. Afr. J. Agric. Res. 7(13):1997-2003.

Moss, A. R., J. P. Jouany, and J. Newbold. 2000. Methane production by ruminants: its contribution to global warming. Ann. Zootech. 49:231-253.

Newbold, C. J., F. M. McInstosh, P. Williams, R. Losa, and R. J. Wallace. 2004. Effects of a specific blend of essential oil compounds on rumen fermentation. Anim. Feed Sci. Technol. 114:105-112.

Patra, A. K. and J. Saxena. 2009. Dietary phytochemicals as rumen modifiers: A review of the effects on microbial populations. Antonie Van Leeuwenhoek 96:363-375.

Patra, A. K., D. N. Kamra, and N. Agarwal. 2010. Effects of extracts of spices on rumen methanogenesis, enzyme activities and fermentation of feeds in vitro. J. Sci. Food Agric. 90:511520

Salem, A. Z. M., M. Z. M. Salem, M. M El-Adawy, and P. H. Robinson. 2006. Nutritive evaluations of some browse tree foliages during the dry season: Secondary compounds, feed intake and in vivo digestibility in sheep and goats. Anim. Feed Sci. Technol. 127:251-267.

Sallam, S. M. A., I. C. S Bueno, M. E. A. Nasser, and A. L. Abdalla. 2010. Effect of eucalyptus (Eucalyptus citriodora) fresh or residue leaves on methane emission in vitro. Ital. J. Anim. Sci. 9: e58. 
Sallam, S. M. A., M. E. A. Nasser, R. C. Araujo, and A. L. Abdalla. 2009. Methane emission in vivo by sheep consuming diet with different levels of eucalyptus essential oil. In proc. FAO/IAEA Int. Symp. on sustainable improvement of animal production and health, Vienna, Autralia. pp. 210-211.

Samuel, M., S. Sagathewan, J. Thomas, and G. Mathen. 1997. An HPLC method for estimation of volatile fatty acids of ruminal fluid. Indian J. Anim. Sci. 67:805-807.

Santos, M. B., P. H. Robinson, P. Williams, and R. Losa. 2010. Effects of addition of an essential oil complex to the diet of lactating dairy cows on whole tract digestion of nutrients and productive performance. Anim. Feed Sci. Technol. 157: 64-71.

SAS. 1998. SAS/STAT User's Guid 6. 12th ed. SAS Institue Inc., Cary, NC, USA.

Steel, R. G. D. and J. H. Torrie. 1980. Principles and procedures of statistics: A biometrical approach. $2^{\text {nd }}$ ed. McGraw-Hill Book Company, New York, NY, USA.

Thao, N. T., M. Wanapat, A. Cherdthong, and S. Kang. 2014. Effects of eucalyptus crude oils supplementation on rumen fermentation, microorganism and nutrient digestibility in swamp buffaloes. Asian Australas. J. Anim. Sci. 27:46-54.

Van Soest, P. J., J. B. Robertson, and B. A. Lewis 1991. Methods for dietary fiber, neutral detergent fiber and non-starch polysaccharides in relation to animal nutrition. J. Dairy Sci. 74:3583-3597.
Wallace, R. J., D. Colombatto, and P. H. Robinson. 2008. Enzymes, direct-fed microbials and plant extracts in ruminant nutrition. Anim. Feed Sci. Technol. 145:1-4.

Wanapat, M., S. Kang, and S. Polyorach. 2013a. Development of feeding systems and strategies of supplementation to enhance rumen fermentation and ruminant production in the tropics. J. Anim. Sci. Biotechnol. 4:32.

Wanapat, M., S. Kang, and K. Phetsatcha. 2013b. Enhancing buffalo production efficiency through rumen manipulation and nutrition. Buffalo Bull. 32(Special Issue 1):258-275.

Wanapat, M., S. Kang, P. Khejornsart, and S. Wanapat. 2013c. Effects of plant herb combination supplementation on rumen fermentation and nutrient digestibility in beef cattle. Asian Australas. J. Anim. Sci. 26:1127-1136.

Wanapat, M., S. Kang, N. Hankla, and K. Phesatcha. 2013d. Effect of rice straw treatment on feed intake, rumen fermentation and milk production in lactating dairy cows. Afr. J. Agric. Res. 8:1677-1687.

Wanapat, M., V. Chanthakhoun, K. Phesatcha, and S. Kang. 2014. Influence of mangosteen peel powder as a source of plant secondary compounds on rumen microorganisms, volatile fatty acids, methane and microbial protein synthesis in swamp buffaloes. Livest. Sci. 162:126-133.

Wang, C. J., S. P. Wang, and H. Zhou. 2009. Influences of flavomycin, ropadiar, and saponin on nutrient digestibility, rumen fermentation, and methane emission from sheep. Anim. Feed Sci. Technol. 148:157-166. 